\title{
ODREĐIVANJE SPECIJA ANORGANSKOG ARSENA U EKSTRAKTIMA ZEMLJIŠTA JEDNOSTAVNOM SPEKTROFOTOMETRIJSKOM METODOM
}

\section{Determination of inorganic arsenic species in soil extracts by a simple spectrophotometric method}

\author{
Azra Tahirović ${ }^{1}$, Amira Čopra-Janićijević ${ }^{2}$, Kurt Kalcher ${ }^{3}$
}

\begin{abstract}
A simple and inexpensive method for the determination of inorganic As(III) and $\operatorname{As}(\mathrm{V})$ at low ppb levels was developed. The method is based on formation of hydride from a sample solution and its reaction with mercury bromide on a solid support. Formation of a yellow-brownish product was optically detected.

Amidosulfonic acid was used as a reaction medium for determination of total inorganic arsenic, while citrate buffer $\left(0.1 \mathrm{~mol} / \mathrm{dm}^{3}, \mathrm{pH}=5.5\right)$ was used as a reaction media for determination of $\mathrm{As}(\mathrm{III})$ alone. $\mathrm{As}(\mathrm{V})$ was calculated as a difference of total inorganic arsenic and As(III).

This method has been applied to soil extracts. Extraction of inorganic arsenic from soil samples was done in three-step sequential extraction with the following extractants: $\mathrm{NH}_{4} \mathrm{H}_{2} \mathrm{PO}_{4}\left(0.05 \mathrm{~mol} / \mathrm{dm}^{3}\right) ; \mathrm{NH}_{4}$-oxalate buffer $\left(0.2 \mathrm{~mol} / \mathrm{dm}^{3}, \mathrm{pH}=3.25\right)$; and mixture of $\mathrm{NH}_{4}$-oxalate buffer $\left(0.2 \mathrm{~mol} / \mathrm{dm}^{3}\right)$ and ascorbic acid $\left(0.1 \mathrm{~mol} / \mathrm{dm}^{3}\right)$ at $\mathrm{pH}=3.25$. The method was suitable for determination of inorganic arsenic species in soil extracts covering concentration range of the analyte between $0.2-20 \mathrm{ppb}$.
\end{abstract}

Key words: hydride generation, selective reduction, sequential extraction, forest soils

\section{Izvod}

Razvijena je jednostavna i jeftina metoda za određivanje anorganskog arsena $\mathrm{u}$ niskom ppb koncentracijskom području. Metoda je zasnovana na formiranju hidrida u rastvoru uzorka i njegovoj reakciji sa živa(II) bromidom na čvrstom nosaču. Formiranje žuto-smeđeg produkta je praćeno optički. Amidosulfonska kiselina je

\footnotetext{
${ }^{1}$ Šumarski fakultet Univerziteta u Sarajevu - Faculty of Forestry, University of Sarajevo

${ }^{2}$ Prirodno-matematički fakultet Univerziteta u Sarajevu - Faculty of Science University of Sarajevo

${ }^{3}$ Institut za hemiju, Karl-Franzens Univerziteta, Graz, Austrija - Institute for Chemistry, Karl-Franzens University, Graz, Austria
} 
korištena kao reakcioni medij za određivanje ukupnog anorganskog arsena, dok je citratni pufer $\left(0,1 \mathrm{~mol} / \mathrm{dm}^{3}, \mathrm{pH}=5,5\right)$ korišten kao reakcioni medij za određivanje samo $\mathrm{As}(\mathrm{III})$. As(V) je izračunat kao razlika koncentracija ukupnog anorganskog arsena i As(III).

Metoda je primijenjena na ekstrakte zemljišta. Ekstrakcija anorganskog arsena iz zemljišta je vršena sekvencijalnom ekstrakcijom u tri stepena sa sljedećim ekstraktantima: $\mathrm{NH}_{4} \mathrm{H}_{2} \mathrm{PO}_{4}\left(0,05 \mathrm{~mol} / \mathrm{dm}^{3}\right), \mathrm{NH}_{4}$-oksalatni pufer $\left(0,2 \mathrm{~mol} / \mathrm{dm}^{3}\right.$, $\mathrm{pH}=3,25)$ i smjesa $\mathrm{NH}_{4}$-oksalatnog pufera $\left(0,2 \mathrm{~mol} / \mathrm{dm}^{3}\right)$, i askorbinske kiseline $(0,1$ $\left.\mathrm{mol} / \mathrm{dm}^{3}\right)$ na $\mathrm{pH}=3,25$. Metoda je pogodna za određivanje specija anorganskog arsena u ekstraktima zemljišta u koncentracijskom području analita 0,2 - 20 ppb.

Kliučne riječi: hidridno generiranje, selektivna redukcija, sekvencijalna ekstrakcija, šumska zemljišta

\section{UVOD - Introduction}

Arsen se susreće $\mathrm{u}$ različitim oblicima $\mathrm{u}$ prirodi $\mathrm{i}$ živim organizmima. Jedinjenja arsena podložna su različitim transformacijama kao rezultat geohemijskih procesa i biohemijskih reakcija u živim organizmima (CULLEN I REIMER, 1989). Najvažnija jedinjenja arsena u prirodi su oksokiseline As(III) i As(V). Anorganska jedinjenja arsena su najtoksičnije specije arsena. Metilirana jedinjenja arsena, kao što su: monometilarsonska kiselina (MMA), dimetilarsinska kiselina (DMA), manje su toksična i u prirodi se nalaze zajedno sa dominantno zastupljenim anorganskim jedinjenjima (Cullen I ReIMeR, 1989; AdRIANo, 1986; SEILER I DR., 1994). Iz tih razloga je neophodno prilikom kvantitativnih određivanja uzeti u obzir vrstu jedinjenja kako bi se mogla vršiti procjena biološke raspoloživosti i toksičnosti.

Kombinacija toksičnosti jedinjenja arsena i njihova široka zastupljenost stvara potrebu za efektivnijim praćenjem i mjerenjem arsena $u$ prirodnim uzorcima (zemljište, voda). Za razliku od organskih polutanata, arsen se ne može transformisati $\mathrm{u}$ netoksični materijal, tj. može biti transformisan samo u manje toksične pojavne oblike u živim organizmima. Zbog toga postoji potreba za razvojem metoda koje će omogućiti dugoročni monitoring na mjestima antropogene depozicije arsena ili mjestima njegove prirodne zastupljenosti u većim koncentracijama. Pregled dosadašnjih metoda koje su primjenjivane $u$ terenskim određivanjima arsena $u$ uzorcima tla, vode i otpadnom materijalu, detaljno je opisan u preglednom radu D. MelAmED-A (2004), u okviru izvještaja Agencije za zaštitu okoliša (EPA, USA). S obzirom na različit stepen toksičnost ovih jedinjenja, razvoj tehnika za određivanje tačno određenih specija nekog elementa dobiva sve više na značaju. Ovakve tehnike omogućavaju bolju procjenu biološke raspoloživosti elementa kao i stepena njegove toksičnosti.

Značajan broj tehnika se koristi u specijaciji arsena. Obično se vrši kombinacija dvije metode, jedne separacione (GC ili HPLC) i druge koja ima ulogu 
element-specifičnog detektora. Kao element-specifični detektori koriste se: plamena AAS (ZENG I DR., 1998), HGAAS (TYE, 1985; MANNING I MARTENS, 1997), GFAAS (PACEY I FORD, 1981), ICP AES i ICP MS (THOMAS, 1997). Obje hromatografije (GC i HPLC) su korištene kao separacione tehnike u kombinaciji sa detektorima FAAS, AFS i ICP-OES (EBDON I DR., 1988). Gasna hromatografija se koristi u separaciji hidrida arsena, dok HPLC ima primjenu u separaciji jedinjenja arsena u rastvorima prije detekcije. Najveće osjetljivosti se postižu upotrebom ICP-MS ili ICP-OES detektorskih sistema, gdje se limiti detekcije kreću u niskom pg/g koncentracijskom području. Jedna od najviše korištenih tehnika, a relativno jeftinijih u odnosu na gore pomenute, jeste HG AAS. To je tehnika koja se može direktno primijeniti u specijacijskoj analizi arsena (WELZ, 1998). Određivanje arsena se izvodi redukcijom njegovih jedinjenja do odgovarajućih hidrida upotrebom natrij borhidrida kao reducenta. Selektivno određivanje je moguće redukcijom jedinjenja arsena u medijima različite kiselosti. Redukcija zavisi od $\mathrm{pKa}$ vrijednosti specija, te se potpuno protonirane molekule analita mogu reducirati sa natrij borhidridom (HOWARD, 1997). Različiti puferi kao što su acetatni $(\mathrm{pH}=5)$ (LOPEZ I DR., 1992; DRIEHAUS I JEKEL, 1992; ANDERSON I DR., 1986; TORRALBA I DR., 1994); citratni pufer ( $\mathrm{pH}=4.5)$ (ANDERSON I DR., 1986; TORRALBA I DR., 1994; BERMEJO-BARRERA, 1998) su korišteni u selektivnom određivanju As(III) u prisustvu As(V), MMA, DMA. Određivanje anorganskog As(III) i As(V) je izvođeno u 6 M HCl (LOPEZ I DR., 1992; TORRALBA I DR., 1994), 5 M HCl (Driehaus I Jekel, 1992; Aggett I Aspell, 1976), 8 M perhloratnoj kiselini (SHRAIM, 2000).

Određivanje As(III), As(V), DMA i MMA, zasnovano na prikupljanju hidrida i njihovoj selektivnoj volatilizaciji, navedeno je od strane više autora (HOWARD I ARBABZAVAR, 1981; MICHEL I DR., 1992; TSALEV I DR., 1995). Selektivno određivanje jedinjenja arsena hidridnim generiranjem vršeno je u različitim reakcionim medijima $i$ hidridi su određivani ETAAS metodom sa in situ prekoncentracijom na presvučenoj grafitnoj cijevi (BERMEJO-BARRERA I DR., 1998), taloženjem na aluminij hidroksidu sa HG AAS (TUZEN I DR., 2009), te prekoncentriranjem na koloni FIA HG AAS (NARCISE I DR., 2005; MELAMED, 2005). Detaljnije informacije o razvoju i aplikaciji tehnika u specijaciji jedinjenja arsena mogu se pronaći u preglednim radovima (TERLECKA, 2005; WANG I MULLIGAN, 2008).

Većina tehnika korištenih u specijaciji arsena zahtijeva primjenu skupe analitičke opreme, koja nije dostupna u svim laboratorijama i nije adekvatna za rutinske analize. Zbog toga je neophodno raditi na razvoju novih metoda koje će omogućiti određivanje toksičnih jedinjenja arsena po prihvatljivoj cijeni, a ujedno se mogu koristiti za brze skrining analize. U ovom radu je opisan razvoj metode za određivanje jedinjenja anorganskog arsena $u$ ekstraktima zemljišta primjenom jednostavnog spektrofotometrijskog uređaja. Metoda je testirana u određivanju ukupnog arsena u zemljištu nakon mineralizacije, što je detaljno opisano u našem prethodnom radu (TAHIROVIĆ I DR., 2010). Primijenjeno je selektivno formiranje hidrida iz rastvora različite kiselosti upotrebom natrij borhidrida kao reducenta. 


\section{MATERIJALI I METODE - Materials and Methods \\ Instrument i način rada - Instruments and work methods}

Za kvantitativno određivanje arsena korišten je jednostavan uređaj SupraLab FD. Aparat je konstruisan na Institutu za analitičku hemiju Karl-Franzens Univerziteta u Grazu, Austrija (MODEREgGer, 1998). Detaljan shematski opis instrumenta naveden je u prethodnoj studiji (TAHIROVIĆ I DR., 2010).

Samo određivanje specija arsena je zasnovano na spektrofotometrijskom određivanju obojenog produkta nepoznatog molekulskog sastava koji se formira kao rezultat reakcije gasovitog hidrida arsena i živa(II) bromida impregniranog na filter papir. Formiranje arsina vrši se $\mathrm{u}$ reakcionoj posudi volumena $100 \mathrm{~cm}^{3}$ iz rastvora arsenita $\mathrm{i} / \mathrm{ili}$ arsenata, pri čemu se podešavanjem $\mathrm{pH}$ rastvora, upotrebom amidosulfonske kiseline ili pufera, omogućava selektivno formiranje arsina. Hidrid, formiran tokom reakcije, prolazi kroz plastični adapter opremljen filter papirima impregniranim olovo acetatom $\mathrm{i}$ vatom $(0,1 \mathrm{~g})$ kako bi se uklonile aerosoli vode $\mathrm{i}$ eventualno prisutni hidrogen sulfid. Tokom određivanja samog As(III), dodatnih $0,1 \mathrm{~g}$ vate je smješteno u sulfidni absorber. $U$ detektorskoj ćeliji formirani hidrid reaguje sa živa(II) bromidom pri čemu se formira žuto-smeđi produkt. Intenzitet boje formiranog produkta prati se optički pomoću svjetlosno emitirajuće diode (LED-a) i detektora fotodiode $(\lambda \max =550 \mathrm{~nm}) \mathrm{u}$ transmisionom modu. Plavo svjetlo sa izvora zračenja prolazi kroz filter papir, a propušteno svjetlo se na detektoru linearno transformiše $u$ fotostruju odgovarajuće jačine. Signal se dalje pojačava i prevodi kao napon do analogno digitalnog pretvarača te prevodi $u$ bite. Binarni podaci se prenose odgovarajućim softverom na računar prateći on-line formiranje hidrida. 1 bit odgovara naponu od $4 \mathrm{mV}$.

\section{Interpretacija rezultata - Interpretation of results}

Snimani su signali $\mathrm{u}$ vremenskom periodu od pet minuta pomoću odgovarajućeg softvera. Dobiveni signali uzoraka, kao i slijepih proba, uzeti su za kvantifikaciju. Ukupna razlika signala $\left(\Delta \mathrm{U}_{0}\right)$ je dobivena kao razlika početnog signala $\left(\mathrm{U}_{0}\right)$ i signala na kraju reakcije $\left(\mathrm{U}_{\mathrm{e}}\right)$. Razlika signala $(\Delta \mathrm{U})$ je izračunata prema formuli:

gdje je: $\Delta \mathrm{U}_{0, \mathrm{~b}}$ razlika signala za slijepu probu.

$$
\Delta \mathrm{U}=\Delta \mathrm{U}_{0}-\Delta \mathrm{U}_{0, \mathrm{~b}}
$$

Apsorpcija zračenja je izračunata prema formuli:

$$
\mathrm{A}=\log (\mathrm{Io} / \mathrm{I})=\log [(\Delta \mathrm{Uo}, \mathrm{c}-\Delta \mathrm{Uo}, \mathrm{b}) /(\Delta \mathrm{Uo}, \mathrm{c}-\Delta \mathrm{Uo}, \mathrm{s})]
$$

gdje je: $\Delta \mathrm{U}_{0, \mathrm{~b}}$ razlika signala slijepe probe; $\Delta \mathrm{U}_{0, \mathrm{~s}}-$ razlika signala uzorka; $\Delta \mathrm{U}_{0, \mathrm{c}}-$ razlika signala za potpunu reakciju sa živa(II) bromidom. 
$\Delta \mathrm{U}_{0, \mathrm{c}}$ je određena eksperimentalno mjerenjem signala standarda sa sadržajem arsena od $50 \mu \mathrm{g}$ (apsolutna vrijednost) i iznosi 992 bita.

\section{Reagensi - Reagents}

Svi reagensi su bili analitičkog stepena čistoće ili većeg. Dejonizirana voda pripremljena upotrebom Mill -Q-sistema korištena je za pripremu svih rastvora.

Standardni rastvori As(III) i As(V) koncentracije $1000 \mathrm{mg} / \mathrm{dm}^{3} \quad \mathrm{su}$ pripremljeni rastvaranjem odgovarajuće količine natrij(meta)arsenita $\mathrm{i}$ dinatrij hidrogenarsenata. Askorbinska kiselina u koncentraciji $0,1 \mathrm{~mol} / \mathrm{dm}^{3}$ dodana je $u$ standardni rastvor As(III) kako bi se spriječila oksidacija arsenita do arsenata. Rastvori arsenita i arsenata manje koncentracije $\left(1 \mathrm{mg} / \mathrm{dm}^{3}\right)$ pripremani su dnevno, a korišteni su za pripremu radnih rastvora.

Amidosulfonska kiselina je korištena u formi tableta, pri čemu je sadržaj kiseline po jednoj tableti iznosio 1,7800 g. Natrij borhidrid je korišten u obliku tableta pri čemu je sadržaj borhidrida iznosio $0,3000 \mathrm{~g} \mathrm{u} 5 \mathrm{~g}$ matrika (natrij hlorida) po jednoj tableti.

Citratni pufer $\left(0,1 \mathrm{~mol} / \mathrm{dm}^{3}, \mathrm{pH}=5,5\right)$ je pripreman upotrebom citratne kiseline i rastvora natrij hidroksida $\left(5 \mathrm{~mol} / \mathrm{dm}^{3}\right)$. Citratni pufer je pripremljen podešavanjem odgovarajućeg $\mathrm{pH}$ rastvora otopini citratne kiseline $\left(0,1 \mathrm{~mol} / \mathrm{dm}^{3}\right)$ rastvorom natrij hidroksida $\left(5 \mathrm{~mol} / \mathrm{dm}^{3}\right)$ upotrebom $\mathrm{pH}$-metra (Model 710A, Orion). Rastvorima oksalne kiseline i smjese oksalne i askorbinske kiseline, podešen je $\mathrm{pH}=$ 3,25 amonijačnim rastvorom (1:1) pH-metrom.

\section{Procedure - Procedures}

\section{Uzorkovanje i priprema uzoraka - Soil sampling and sample preparation.}

Uzorci šumskog zemljišta su uzeti na dvije lokacije područja centralne Bosne. Prvo mjesto uzorkovanja se nalazi u neposrednoj blizini grada Vareša. Uzorci su uzeti na lokalitetu rudnika Veovača u Šumsko-gospodarskoj jedinici "Gornja Stavnja”. Drugo mjesto uzorkovanja nalazi se na planini Vranici, u blizini grada Fojnice, a uzorkovanje je vršeno na lokalitetu "Jezernica" i predstavlja tipično šumsko ruralno područje.

Na svakoj lokaciji je označena ploha dimenzije 20 x 20 m, a uzorkovanje je vršeno na dubini $12-22 \mathrm{~cm}$. Uzeto je više pojedinačnih uzoraka na svakoj plohi čijim miješanjem su dobiveni reprezentativni uzorci. Uzorci su sušeni na sobnoj temperaturi, prosijani na sito promjera $2 \mathrm{~mm}$ i homogenizirani. Uzorci su dalje prosijani na mikrosito i pohranjeni $u$ frižider na $4^{\circ} \mathrm{C}$ do analize. 


\section{Određivanje ukupnog anorganskog arsena - Determination of total inorganic arsenic}

Rastvor uzorka $\left(50 \mathrm{~cm}^{3}\right)$ je smješten u hidridni generator i dodane su dvije tablete amidosulfonske kiseline (3,560 $\mathrm{g}$ čiste kiseline) $\mathrm{i}$ jedna tableta natrij borhidrida $(0,3000 \mathrm{~g}$ čistog borhidrida). Detektorska ćelija sa plastičnim adapterom je montirana na reakcionu posudu i započeto je snimanje signala.

\section{Određivanje As(III) - Determination of As(III)}

Rastvor uzorka $\left(50 \mathrm{~cm}^{3}\right)$ je pripremljen odgovarajućim razblaženjem odabranog alikvota uzorka u citratnom puferu $\left(0,1 \mathrm{~mol} / \mathrm{dm}^{3}, \mathrm{pH}=5,5\right)$, dodana je tableta natrij borhidrida, nakon čega je određivanje izvršeno prema postupku opisanom za ukupni anorganski arsen.

\section{Određivanje As(V) - Determination of $A s(V)$}

Vrijednost koncentracije $\mathrm{As}(\mathrm{V})$ je dobivena računski kao razlika koncentracija ukupnog anorganskog arsena i As(III).

\section{Određivanje ukupnog arsena - Determination of total arsenic}

Određivanje ukupnog anorganskog arsena nakon mikrovalnog rastvaranja (MIS-ETHOS 1600 Microwellen Laborsystem, Leutkirche, Germany) uzoraka zemljišta $(0,2000 \mathrm{~g})$ u smjesi nitratne $(65 \%)$ i hidrogen peroksida $(30 \%)$, izvršeno je prema proceduri opisanoj za ukupni anorganski arsen. Detaljan opis procedure naveden je u prethodnoj studiji (TAHIROVIĆ I DR., 2010).

\section{Sekvencijalna ekstrakcija - Sequential extraction}

U radu je korištena modificirana procedura ekstrakcije arsena iz zemljišta po WENZEL-U (2001). U posudi za centrifugiranje $\left(50 \mathrm{~cm}^{3}\right)$ odvagano je $1,0000 \mathrm{~g}$ uzorka zemljišta i dodana je odgovarajuća količina ekstraktanta (tabela 1). Ekstraktanti su prethodno deareisani propuštanjem argona 20 minuta i još dodatnih 2 minute nakon dodatka rastvora uzorku zemljišta. Ekstrakcija je vršena 20 minuta centrifugiranjem na $2500 \mathrm{rpm}$ u centrifugi (B3-11, Jouan Laboratory Equipment, St. Nazaire, France) za svaki korak ekstrakcije. Nakon centrifugiranja, rastvor je filtriran kroz $0,22 \mu \mathrm{m}$ injekcione filtere (Cameo, Osmonics) u graduisane posude $\mathrm{i}$ analiziran je prema prethodno navedenim procedurama za ukupni anorganski arsen i As(III). Detaljan analitički postupak ekstrakcije naveden je u tabeli 1 . 
Tabela 1. Sekvencijalna procedura ekstrakcije

Table 1. Sequential extraction procedure

\begin{tabular}{|c|c|c|c|c|}
\hline $\begin{array}{c}\text { Frakcija } \\
\text { Fraction }\end{array}$ & $\begin{array}{c}\text { Ekstraktant } \\
\text { Extractant }\end{array}$ & $\begin{array}{c}\text { Uslovi ekstrakcije } \\
\text { Extraction } \\
\text { conditions }\end{array}$ & $\mathrm{SSR}^{\mathrm{a}}$ & $\begin{array}{c}\text { Korak ispiranja } \\
\text { Wash step }\end{array}$ \\
\hline 1 & $\begin{array}{c}\left(\mathrm{NH}_{4}\right) \mathrm{H}_{2} \mathrm{PO}_{4} \\
(0,05 \mathrm{M})\end{array}$ & $\begin{array}{c}16 \mathrm{~h} \text { mućkanja } \\
\text { na } 20^{\circ} \mathrm{C}\end{array}$ & $1: 25$ & - \\
\hline 2 & $\begin{array}{c}\mathrm{NH}_{4} \text {-oksalatni pufer } \\
(0,2 \mathrm{M}, \mathrm{pH}=3,25)\end{array}$ & $\begin{array}{c}4 \mathrm{~h} \text { mućkanja u } \\
\text { mraku; } 20^{\circ} \mathrm{C}\end{array}$ & $1: 25$ & $\begin{array}{c}\mathrm{NH}_{4} \text {-oksalat } \\
(0,2 \mathrm{M} \mathrm{pH}=3,25) \\
\mathrm{SSR} 1: 12,5 \\
10 \text { minuta mućkanja }\end{array}$ \\
\hline 3 & $\begin{array}{c}\mathrm{NH}_{4} \text {-oksalatni pufer } \\
0,2 \mathrm{M}+\text { askorbinska } \\
\text { kiselina } 0,1 \mathrm{M}, \\
\mathrm{pH}=3,25)\end{array}$ & $\begin{array}{c}30 \text { min na } \\
\text { vodenom kupatilu } \\
\text { na } 96 \pm 3^{\circ} \mathrm{C}\end{array}$ & $1: 25$ & $\begin{array}{c}\mathrm{NH}_{4} \text {-oksalat } \\
(0,2 \mathrm{M} \mathrm{pH}=3,25) \\
\text { SSR } 1: 12,5 \\
10 \text { minuta mućkanja }\end{array}$ \\
\hline
\end{tabular}

${ }^{\mathrm{a}} \mathrm{SSR}$ odnos tlo: ekstraktant - SSR soil solution ratio

\section{REZULTATI - Results}

\section{Optimizacija eksperimentalnih parametara - Optimization of experimental parameters}

\section{Kiselost - Acidity}

Da bi se izvršilo određivanje samog arsenita, redukcija arsenata mora biti svedena na najmanju moguću mjeru ukoliko su obje specije prisutne u rastvoru. Citratni pufer $\left(0,1 \mathrm{~mol} / \mathrm{dm}^{3}\right)$ je korišten kao reakcioni medij za ispitivanje redukcije arsenita $\mathrm{i}$ arsenata na različitim $\mathrm{pH}$ vrijednostima uz reducent natrij borhidrid. Ispitivanja su vršena sa standardnim rastvorima arsenita $i$ arsenata $u$ koncentracijama od po $10 \mu \mathrm{g} / \mathrm{dm}^{3}$, primijenjenih pojedinačno ili u smjesi. Redukcija je vršena dodatkom jedne tablete natrij borhidrida. Ovisnosti razlika signala $(\Delta U)$ arsenita $i$ arsenata su ispitivane u području $\mathrm{pH}$ između 3 i 6 . Dobiveni rezultati su prikazani na dijagramu 1. 


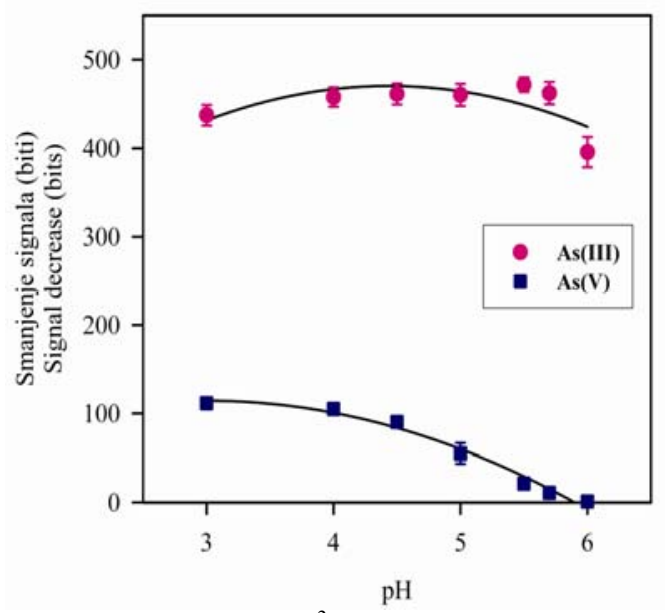

Dijagram 1. Utjecaj citratnog pufera $\left(0,1 \mathrm{~mol} / \mathrm{dm}^{3}\right)$ na formiranje arsina iz rastvora arsenita i arsenata. Figure 1. Influence of the citrate buffer $\left(0,1 \mathrm{~mol} / \mathrm{dm}^{3}\right)$ on the hydride generation of arsane from solutions of arsenite and arsenate.

Budući da $\mathrm{As}(\mathrm{V})$ daje uočljiv signal do $\mathrm{pH}=5$, područje $\mathrm{pH}$ između 5 i 6 je detaljnije ispitivano. Dobiveni rezultati su prikazani na dijagramu 2 kao ovisnost razlike signala $(\Delta \mathrm{U})$ od promjene $\mathrm{pH}$ rastvora. Ispitivanje je sprovedeno sa rastvorima samog $\mathrm{As}(\mathrm{III})$ i samog $\mathrm{As}(\mathrm{V})$, kao i smjesom obje komponente dodane u koncentraciji od po 10 $\mu \mathrm{g} / \mathrm{dm}^{3}$ svakog. Redukcija je vršena dodatkom jedne tablete natrij borhidrida.

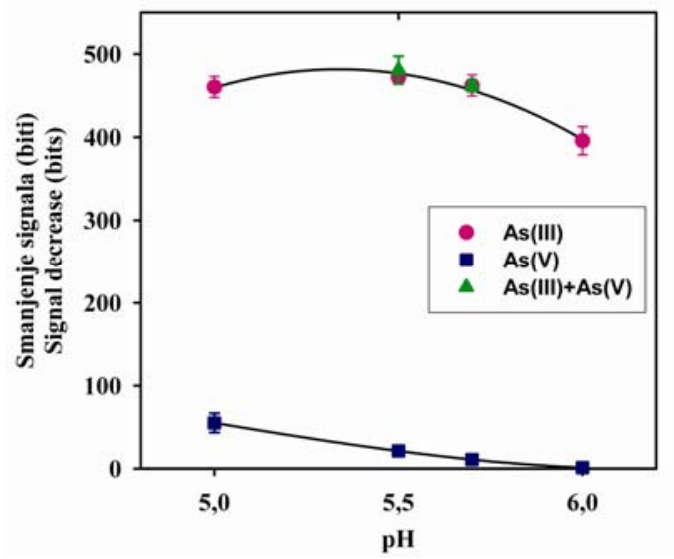

Dijagram 2. Utjecaj $\mathrm{pH}$ rastvora na formiranje hidrida; $\mathrm{As}(\mathrm{III}), \mathrm{As}(\mathrm{V})\left(10 \mu \mathrm{g} / \mathrm{dm}^{3}\right.$ svakog $)$ i njihove smjese (ukupno $20 \mu \mathrm{g} / \mathrm{dm}^{3}$ ).

Figure 2. Influence of the $\mathrm{pH}$ on hydride generation; $A s(I I I), A s(V)\left(10 \mu \mathrm{g} / \mathrm{dm}^{3}\right.$ of each) and their mixture (total $20 \mu \mathrm{g} / \mathrm{dm}^{3}$ ). 
Signali As(III) (pojedinačno i u smjesi) su bili vrlo slični između pH 5 i 5,7. Provjereno je ponašanje ispitivanih specija na niskim koncentracijama $(0,2$ i 1 $\mu \mathrm{g} / \mathrm{dm}^{3}$ ). Procenti iskorištenja dobiveni na $\mathrm{pH}=5,7$ su bili signifikatno niži, te su iznosili $90 \%$ za arsenit i $92,5 \%$ za smjesu. Dobra iskorištenja su dobivena za ispitivane koncentracije na $\mathrm{pH}=5,5$ i iznosila su $98,5 \%$ za As(III) i $102 \%$ za smjesu As(III) i As(V), zbog čega je vrijednost $\mathrm{pH}=5,5$ odabrana kao optimalna za određivanje As(III).

\section{Zavisnost reakcije od vremena - Time dependence}

Ispitivana je zavisnost reakcije u vremenu za As(III) u citratnom puferu na različitim koncentracijama analita. Rezultati pokazuju da je vrijeme od pet minuta dovoljno za kompletnu redukciju arsenita neovisno od primjenjene koncentracije (dijagram 3). Dobiveni rezultati su u dobrom slaganju sa rezultatima za redukciju As(III) u kiselom mediju (amidosulfonska kiselina).

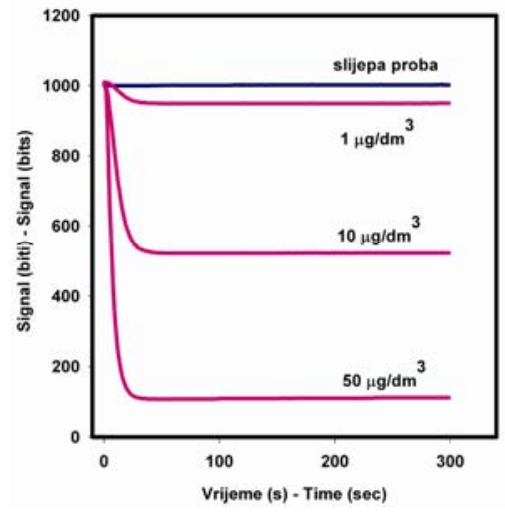

Dijagram 3. Zavisnost signala od vremena za As(III) u citratnom puferu $\left(0,1 \mathrm{~mol} / \mathrm{dm}^{3}, \mathrm{pH}=5,5\right)$. Figure 3. Response curves of As(III) in citrate buffer $\left(0.1 \mathrm{~mol} / \mathrm{dm}^{3}, \mathrm{pH}=5.5\right)$.

\section{Kalibracione krive - Calibration curves}

Kako bi se izvršilo određivanje samog As(III), izvršena su mjerenja signala standardnih otopina različite koncentracije As(III) u citratnom puferu $\left(0,1 \mathrm{~mol} / \mathrm{dm}^{3}\right.$, $\mathrm{pH}=5,5)$. Razlika signala $(\Delta \mathrm{U})$ je komparirana sa razlikom signala standardnih rastvora $\mathrm{As}(\mathrm{III})$ u rastvoru amidosulfonske kiseline i predstavljena je na dijagramu 4. Stepen iskorištenja As(III) u citratnom puferu u odnosu na As(III), u amidosulfonskoj kiselini, kretao se u području 98,4-100\%. 


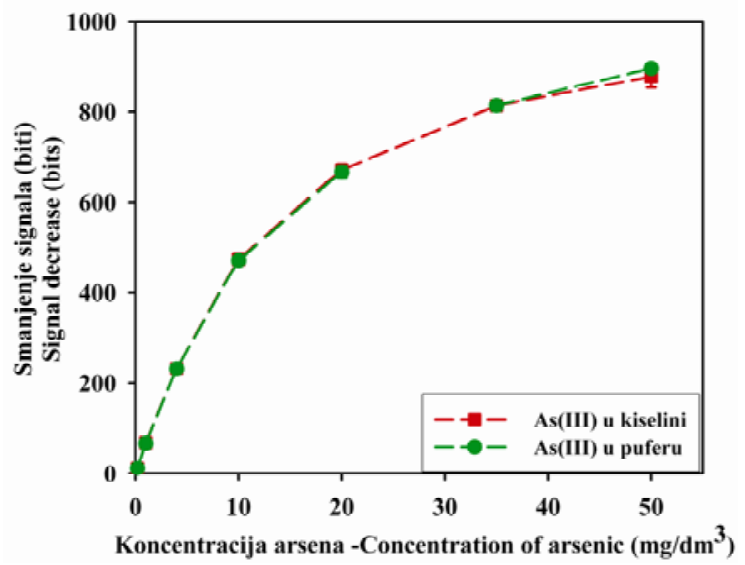

Dijagram 4. Poređenje razlike signala As(III) u citratnom puferu i As(III) u amidosulfonskoj kiselini. Figure 4. Comparison of signal decrease of As(III) in citrate buffer and As(III) in amidosulfonic acid.

U cijelom ispitivanom koncentracijskom području $\left(0,2-50 \mu \mathrm{g} / \mathrm{dm}^{3}\right)$ odgovor As(III) u oba reakciona medija je identičan. Kalibracijska kriva se može koristiti za cijelo ispitivano koncentracijsko područje, ali je za kvantifikaciju korišteno koncentracijsko područje između 0,2 i $20 \mu \mathrm{g} / \mathrm{dm}^{3}$. Podaci su opisani kvadratnom funkcijom sa sljedećim koeficijentima: $\mathrm{a}==-1,85367 \cdot 10^{-3}, \mathrm{~b}=0,031864$, and $\mathrm{c}=$ $3,6367 \cdot 10^{-4}$ sa faktorom korelacije $r^{2}=0,99990$. Relativna standardna devijacija (RSD), za koncentraciju $10 \mu \mathrm{g}$ As $/ \mathrm{dm}^{3}$ (n=5) je određena i iznosi $\pm 1.7 \%$ za As(III) u citratnom puferu. Limit kvantifikacije je identičan kao i za ukupni anorganski arsen u amidosulfonskoj kiselini i iznosi $0,2 \mu \mathrm{g} \mathrm{As} / \mathrm{dm}^{3}$. Limit detekcije (LOD, $3 \sigma$ vrijednost) procijenjen je koristeći standardnu devijaciju limita kvantifikacije As(III) i iznosi u citratnom puferu $0,07 \mu \mathrm{g}$ As $/ \mathrm{dm}^{3}$.

\section{Određivanje ukupne koncentracije arsena u zemljištima - Determination of total arsenic concentration in soils}

Ukupan arsen u uzorcima zemljišta određen je upotrebom uređaja SupraLab FD nakon mineralizacije uzoraka $\mathrm{u}$ smjesi nitratne i hidrogen peroksida prema prethodno opisanoj proceduri. Za svaki uzorak zemljišta ispitivane su tri paralelke, a rezultati su prikazani kao srednja vrijednost tri ponovljena određivanja. Za uzorke označene $S_{1}$ prosječan sadržaj ukupnog arsena je iznosio $81,14 \pm 1,90 \mathrm{mg} / \mathrm{kg}$, dok je za uzorke zemljišta označene $\mathrm{S}_{2}$ prosječan sadržaj ukupnog arsena iznosio $14.18 \pm 0.62 \mathrm{mg} / \mathrm{kg}$.

Metodom standardnog dodatka ispitivan je efekat matriksa u oba uzorka i dobiveni procenti iskorištenja su se kretali za $S_{1}$ zemljište između 94,0 i $102 \%$, a za zemljište $S_{2}$ 103,0 i $104,0 \%$. Dobiveni podaci su korišteni za procentualno izražavanje ekstraktibilnih frakcija anorganskog arsena. 


\section{Specijacija anorganskog arsena - Speciation of inorganic arsenic}

Određivanje anorganskog arsena u ekstraktima zemljišta je izvršeno na sljedeći način: ukupan anorganski arsen je određivan u kiselom mediju dodatkom dvije tablete amidosulfonske kiseline $\mathrm{i}$ jedne tablete reducenta natrij borhidrida; As(III) je određivan u citratnom puferu $\left(0,1 \mathrm{~mol} / \mathrm{dm}^{3}, \mathrm{pH} 5,5\right)$ uz dodatak jedne tablete natrij borhidrida. Iz razlike ukupnog anorganskog arsena i As(III), dobivene su vrijednosti koncentracija As(V). Tri paralelke su bili uključene u svaki korak ekstrakcije. Za svaku paralelku su izvršena tri mjerenja signala uz provođenje slijepe probe kroz istu proceduru. Koncentracija arsena u zemljišnim ekstraktima je određena upotrebom vanjskih kalibracionih krivih. Metoda standardnog dodatka je korištena za provjeru efekta matriksa. Dobiveni rezultati su prikazani u tabeli 2 i tabeli 3 . Test iskorištenja za specije anorganskog arsena u ekstraktima se kretao između 98,0\% i $103,0 \%$, dok je za As(III) iznosio između 94,2\% i 102\%, što ukazuje na izrazito mali efekat matriksa. U svakom koraku ekstrakcije relativna standardna devijacija ponovljenih mjerenja je bila manja od 5\%.

Tabela 3. Rezultati sekvencijalne ekstrakcije uzoraka zemljišta $\mathrm{S}_{1}$ (Gornja Stavnja) izražene kao srednja vrijednost $\pm \mathrm{SD}$ tri mjerenja za tri paralelke $(\mathrm{n}=3)$.

Table 3. Results of sequential extraction applied on soil $S_{1}$ (Gornja Stavnja) expressed as a mean value $\pm S D$ of three determination in triplicate $(n=3)$.

\begin{tabular}{|c|c|c|c|c|c|}
\hline \multirow[t]{2}{*}{$\begin{array}{c}\text { Broj } \\
\text { uzoraka } \\
\text { (Veovača) } \\
\text { Sample no. }\end{array}$} & \multirow{2}{*}{$\begin{array}{c}\mathrm{NH}_{4} \mathrm{H}_{2} \mathrm{PO}_{4} \\
\text { frakcija } \\
(\mathrm{mg} / \mathrm{kg})\end{array}$} & \multirow{2}{*}{$\begin{array}{c}\begin{array}{c}\mathrm{NH}_{4^{-}} \\
\text {oksalatni } \\
\text { pufer } \\
\text { frakcija } \\
(\mathrm{mg} / \mathrm{kg})\end{array} \\
\mathrm{As}(\mathrm{V})\end{array}$} & \multicolumn{2}{|c|}{$\begin{array}{c}\mathrm{NH}_{4} \mathrm{Oksalatni} \text { pufer } \\
\text { +askorbinska kiselina } \\
\text { frakcija } \\
(\mathrm{mg} / \mathrm{kg})\end{array}$} & \multirow[t]{2}{*}{$\begin{array}{l}\text { Ukupni ekstraktibilni } \\
\text { arsen } \\
\text { Total extr. As } \\
\text { (mg } / \mathrm{kg})\end{array}$} \\
\hline & & & $\mathrm{As}(\mathrm{V})$ & $\mathrm{As}(\mathrm{III})$ & \\
\hline Proba 1 & $0,94 \pm 0,06$ & $8,85 \pm 0,09$ & $50,80 \pm 1,05$ & $2,35 \pm 0,12$ & 62,95 \\
\hline Proba 2 & $0,82 \pm 0,08$ & $8,27 \pm 0,32$ & $53,06 \pm 0,71$ & $2,34 \pm 0,26$ & 64,49 \\
\hline Proba 3 & $0,84 \pm 0,03$ & $8,42 \pm 0,43$ & $53,86 \pm 0,35$ & $2,32 \pm 0,30$ & 65,44 \\
\hline $\begin{array}{c}\text { Sr.vrijednost } \\
\text { Avrg. value } \\
\text { (mg/kg) }\end{array}$ & $0,86 \pm 0,06$ & $8,51 \pm 0,30$ & $52,57 \pm 1,58$ & $2,34 \pm 0.01$ & 64,29 \\
\hline $\begin{array}{c}\text { Sr.vrijednost } \\
\text { Avrg. value } \\
\text { (\%) }\end{array}$ & 1,0 & 10,2 & 63,3 & 2,8 & 77,4 \\
\hline
\end{tabular}


Tabela 4. Rezultati sekvencijalne ekstrakcije uzoraka zemljišta $\mathrm{S}_{2}$ (Jezernica) izražene kao srednja vrijednost \pm SD tri mjerenja za tri paralelke $(\mathrm{n}=3)$.

Table 4. Results of sequential extraction applied on soils $S_{2}$ (Jezernica) expressed as a mean value $\pm S D$ of three determination in triplicate $(n=3)$.

\begin{tabular}{|c|c|c|c|c|c|}
\hline $\begin{array}{c}\text { Broj } \\
\text { uzoraka } \\
\text { Vranica) } \\
\text { Sample no. }\end{array}$ & $\begin{array}{c}\mathrm{NH}_{4} \mathrm{H}_{2} \mathrm{PO}_{4} \\
\text { frakcija } \\
(\mathrm{mg} / \mathrm{kg})\end{array}$ & $\begin{array}{c}\mathrm{NH}_{4} \text {-oksalatni } \\
\text { pufer } \\
\text { frakcija } \\
(\mathrm{mg} / \mathrm{kg})\end{array}$ & \multicolumn{2}{|c|}{$\begin{array}{c}\mathrm{NH}_{4} \text {-oksalatni pufer } \\
\text { askorbinska kiselina } \\
\text { frakcija } \\
(\mathrm{mg} / \mathrm{kg})\end{array}$} & $\begin{array}{c}\text { Ukupni } \\
\text { ekstraktibilni } \\
\text { arsen } \\
\text { Total extr. } \text { As } \\
(\mathrm{mg} / \mathrm{kg})\end{array}$ \\
\hline Proba 1 & $0,37 \pm 0,03$ & $4,31 \pm 0,23$ & $6,65 \pm 0,13$ & $0,19 \pm 0,01$ & 11,54 \\
\hline Proba 2 & $0,34 \pm 0,02$ & $4,25 \pm 0,12$ & $7,40 \pm 0,27$ & $0,21 \pm 0,01$ & 12,21 \\
\hline Proba 3 & $0,39 \pm 0,02$ & $4,49 \pm 0,16$ & $7,74 \pm 0,55$ & $0,22 \pm 0,07$ & 12,83 \\
\hline $\begin{array}{c}\text { Sr.vrijednost } \\
\text { Avrg. value } \\
\text { (mg/kg) }\end{array}$ & $0,37 \pm 0,02$ & $4,35 \pm 0,13$ & $7,26 \pm 0,55$ & $0,21 \pm 0,01$ & $12,19 \pm 0,64$ \\
\hline $\begin{array}{c}\text { Sr.vrijednost } \\
\text { Avrg. value } \\
\text { (\%) }\end{array}$ & 2,6 & 30,7 & 51,2 & 1,5 & 85,9 \\
\hline
\end{tabular}

\section{DISKUSIJA - Discussion}

Određivanje specija anorganskog arsena, arsenita i arsenata, može se izvršiti metodom selektivnog hidridnog generiranja. Metoda se zasniva na određivanju ukupnog anorganskog arsena i samog As(III). Iz razlike dobivenih koncentracija može se dobiti vrijednost koncentracije As(V). Selektivno formiranje hidrida se vrši redukcijom specija As(III) i As(V) u rastvorima različitog aciditeta. Za redukciju obje specije koriste se jake anorganske kiseline kao reakcioni medij, dok redukcija samog As(III) zahtijeva slabo kiselu sredinu što se postiže primjenom pufera na različitim $\mathrm{pH}$ vrijednostima. Citratni pufer je korišten na $\mathrm{pH}=5,5$. Citratna kiselina je triprotonska kiselina čije se vrijednosti pKa nalaze u kiselom području, te je pogodna za pripremu i ispitivanje puferskog dejstva u kiselom mediju. Korišten je $0,1 \mathrm{~mol} / \mathrm{dm}^{3}$ citratni pufer, s obzirom da posjeduje dovoljan kapacitet za kompletnu redukciju arsenita, dok veće koncentracije pufera nisu poboljšale analizu. Ispitivanja zavisnosti signala arsenita i arsenata od $\mathrm{pH} \mathrm{u}$ citratnom puferu su pokazala da je arsenit manje-više potpuno redukovan na $\mathrm{pH}$ vrijednostima između 3 i 5,7. Arsenat daje uočljiv signal do $\mathrm{pH}$, dok iznad ove vrijednosti dolazi do opadanja signala (dijagram 1). Ovakvo ponašanje se može objasniti smanjenim stvaranjem hidrogena kako se $\mathrm{pH}$ vrijednost rastvora približava neutralnom području. Detaljnija ispitivanja reakcije su vršena u području pH između 5 i 6 (dijagram 2). Kao optimalan pH na kojem će se vršiti redukcija samo 
As(III) odabran je $\mathrm{pH}=5,5 \mathrm{~s}$ obzirom da su dobiveni procenti iskorištenja za As(III) sam i u smjesi sa $\mathrm{As}(\mathrm{V})$ bili bolji na datoj $\mathrm{pH}$ vrijednosti u odnosu na procente iskorištenja dobivene na $\mathrm{pH}=5,7$.

Zavisnost reakcije redukcije arsenita u citratnom puferu $\left(0,1 \mathrm{~mol} / \mathrm{dm}^{3}, \mathrm{pH}\right.$ $=5,5$ ) od vremena ispitivana je kako bi se odredilo optimalno vrijeme izvođenja reakcije (dijagram 3). Kinetika reakcije je dosta slična reakciji redukcije arsenita u amidosulfonskoj kiselini. Brzina reakcije je malo veća, što se može objasniti činjenicom da se koristi rastvor citratnog pufera, dok se amidosulfonska kiselina dodaje u čvrstom stanju. Iz tih razloga uzeto je reakciono vrijeme od 5 minuta za izvođenje reakcije u citratnom puferu.

Kako bi se ispitao odgovor različitih koncentracija arsenita u citratnom puferu, izvršena je komparacija dobivenih razlika signala sa razlikama signala arsenita sa amidosulfonskom kiselinom (dijagram 4). Iz dobivenih rezultata se jasno može uočiti da su dobivene razlike signala arsenita u oba reakciona medija identične. Kalibracijska kriva je opisana kvadratnom funkcijom sa sljedećim parametrima: $\mathrm{a}=-1,85367 \cdot 10^{-3}$, $\mathrm{b}=0,031864, \mathrm{c}=-3,6367 \cdot 10^{-4}$ i faktorom korelacije $\mathrm{r}^{2}=0,99990$. Relativna standardna devijacija razlike signala $\Delta \mathrm{U}$ za $10 \mu \mathrm{gAs} / \mathrm{dm}^{3}$ u citratnom puferu iznosi $\pm 1,7 \%$. U radu, TAHIROVIĆ I DR. (2010), detaljno je opisana procedura određivanja As(III) i As(V) u kiseloj sredini uz dodatak amidosulfonske kiseline.

Metode hemijskog frakcioniranja zasnovane na procedurama sekvencijalne ekstrakcije koriste se u određivanju ispitivanog analita u specifičnoj hemijskoj fazi uzorka. Jednu od prvih procedura uveli su TESSIER I DR., (1979) pri čemu su ispitivani metali u tragovima prisutni u pet frakcija: izmjenjivi, vezani za karbonate, vezani za okside željeza i mangana, vezani za organsku materiju i rezidualni. Detaljan pregled različitih metoda sekvencijalne ekstrakcije intenzivno je obrađen od strane više autora (KERSTEN I FORSTNER, 1995; RITCHIE I SPOSITO, 1995).

U frakcioniranju arsena u tlu ili sedimentima korištene su različite procedure ekstrakcije (HIRNER, 1992; HALL I DR., 1996; WENZEL I DR., 2001; SHIOWATANA I DR., 2001; GUPTA I DR., 2001; RODRIQUEZ I DR., 2003). One se, uglavnom, zasnivaju na upotrebi različitih supstanci sa kiselim, reduktivnim ili oksidativnim osobinama. U ovom radu je razmatrana procedura ekstrakcije arsena po WENZEL-u (2001), dizajnirana isključivo za frakcioniranje arsena u zemljištu. Sekvencijalna procedura uključuje više koraka, čime se ispituje stepen mobilnosti arsenovih jedinjenja i jačina fizičke ili hemijske veze sa komponentama zemljišta. Sekvencijalna ekstrakcija je vršena $u$ tri koraka primjenom amonij-dihidrogenfosfata kojim se ekstrahuje specifično vezani arsen na mineralnoj površini (SPOSITO, 1989); amonij-oksalatnim puferom $(\mathrm{pH}=3,25)$ koji ekstrahuje arsen vezan za amorfne i slabo kristalne hidratizirane okside željeza i aluminija, te smjesom amonij-oksalatnog pufera i askorbinske kiseline kojom se ekstrahuje arsen vezan za kristalne hidratizirane okside željeza i aluminija (CHARLET I MINLLAN, 1993; LAISANEN, 1992).

Prije samog određivanja anorganskog arsena u zemljišnim ekstraktima, provjerena su reduktivna svojstva ekstraktanata na standardnom rastvoru arsenata, prema proceduri opisanoj za određivanje As(III) u zemljišnim ekstraktima. Nije 
pronađena promjena $\mathrm{u}$ koncentraciji arsenata $\mathrm{u}$ rastvorima ekstraktanata tokom 48 sati nakon izvršene ekstrakcije. Takođe je ispitana u vodi ekstraktibilna frakcija arsena (WENZEL I DR., 2001), kao i izmjenjiva frakcija arsena upotrebom amonij-sulfata (MILLER I DR., 1986), te je utvrđeno da su koncentracije arsena u ovim ekstraktima ispod limita detekcije metode, što jasno ukazuje na jači stepen vezanosti arsena $u$ ispitivanim uzorcima zemljišta.

Kod oba uzorka zemljišta nije detektovano prisustvo As(III) u ekstraktima dobivenim nakon prva dva stepena ekstrakcije, te je sav ekstrahovani arsen predstavljao $\mathrm{As}(\mathrm{V})$. Ovi rezultati su u saglasnosti s ispitivanjima vršenim na dobro areisanim zemljištima, gdje je pronađeno da je $\mathrm{As}(\mathrm{V})$ dominantno prisutan oblik anorganskog arsena (NG I DR., 1998). Prema YEHL-u (2001), u tlu i sedimentima je arsen uglavnom prisutan $\mathrm{u}$ obliku arsenata $\mathrm{i}$ arsenita, dok su organski oblici (DMA, MMA) daleko manje zastupljeni. Amonij oksalat, kao najjači ekstraktant, ekstrahirati će arsen asociran sa amorfnim i kristalnim oksidima željeza (RODRIGUEZ I DR., 2003; SHRUMAN, 1982). Mobilnost ove frakcije arsena je najmanja i može se povećati promjenom redoks-potencijala. Frakcija u vodi rastvorljivog arsen i lako izmjenjivog arsena nisu bili detektirani u ekstraktima, što ukazuje na jači stepen imobilizacije arsena u ispitivanim uzorcima. Frakcija specifično adsorbovanog arsena je činila 1\% kod uzorka $S_{1}$ i 2,6\% kod uzorka $S_{2}$, te predstavlja mjeru specifično adsorbovanog arsena koji se potencijalno može mobilizirati promjenom $\mathrm{pH}$ vrijednosti zemljišta ili dodatkom fosfora. Najveći sadržaj $\mathrm{As}(\mathrm{V})$ je pronađen u ekstraktima nakon trećeg koraka ekstrakcije i predstavlja arsen vezan za kristalne hidratizirane okside željeza i aluminijuma. Zajedno sa $\mathrm{As}(\mathrm{V})$ vezanim za amorfne i slabo kristalne hidratizirane okside željeza i aluminijuma čini dominantno zastupljen oblik arsena $u$ ispitivanim tlima, koji iznosi prosječno 76,3\% za prvi uzorak i 82,6\% za drugi uzorak. Ovakvi rezultati su u saglasnosti sa istraživanjima sprovedenim od strane drugih autora (WENZEL I DR., 2001; RODRIGUEZ I DR., 2003).

Ukupan prosječan sadržaj ekstraktibilnog arsena za prvi uzorak je iznosio $77,4 \%$, za drugi uzorak zemljišta $85,9 \%$, a ostatak do $100 \%$ predstavlja rezidualni arsen.

Ponovljivost same ekstrakcione procedure je izračunata kao RSD tri ponovljene ekstrakcije za svaki korak ekstrakcije i iznosila je manje od 5\%, što je u dobrom slaganju sa literaturnom vrijednošću (WENZEL I DR., 2001).

\section{ZAKLJUČCI - Conclusions}

- Opisana metoda određivanja anorganskog arsena selektivnim formiranjem hidrida može se primijeniti za određivanje anorganskog arsena u ekstraktima zemljišta primjenom instrumenta SupraLab FD.

- Metoda omogućava određivanje niskih koncentracija $\operatorname{As}(\mathrm{III})$ i $\operatorname{As}(\mathrm{V}) \mathrm{u}$ zemljišnim ekstraktima i primjenjiva je u području koncentracija arsena od 0,2 $\mu \mathrm{g} / \mathrm{dm}^{3}$ do $20 \mu \mathrm{g} / \mathrm{dm}^{3}$. 
- Procenti iskorištenja za specije arsena u uzorku zemljišta $S_{1}$ su se kretali u granicama $98 \%$ do $103 \%$, dok su za uzorke zemljišta $\mathrm{S}_{2}$ iznosile $94,2 \% 102 \%$ ukazujući na vrlo mali efekat matriksa.

- Kod oba uzorka zemljišta, detektirano je prisustvo relativno malih koncentracija ekstraktibilnog As(III) i to samo u trećem koraku ekstrakcije $2,8 \%$ za zemljište $S_{1}$ i $1,5 \%$ za zemljište $S_{2}$.

- $A s(V)$ je bio dominantno prisutan u svim ispitivanim uzorcima zemljišta i čini $62 \%$ prosječnog sadržaja ekstraktibilnog arsena u zemljištu $S_{1}$ i $84,2 \%$ prosječnog sadržaja ekstraktibilnog arsena u zemljištu $\mathrm{S}_{2}$.

- Najveći sadržaj ekstraktibilnog As(V) je detektiran u ekstraktima dobivenim nakon trećeg koraka ekstrakcije, a prosječan sadržaj iznosi $63,3 \%$ za $\mathrm{S}_{1}$ zemljište i $51,2 \%$ za $\mathrm{S}_{2}$ zemljište.

- Najmanji sadržaj prosječnog ekstraktibilnog As(V) je detektiran u ekstraktima dobivenim nakon prvog koraka ekstrakcije i on iznosi $1,0 \%$ za $\mathrm{S}_{1}$ zemljište $\mathrm{i}$ $2,6 \%$ za $\mathrm{S}_{2}$ zemljište.

- Na ukupan ekstraktibilni anorganski arsen u zemljištu $S_{1}$ otpada 77,4\% od prosječnog sadržaja, dok u zemljištu $\mathrm{S}_{2}$ prosječan sadržaj ekstraktibilnog anorganskog arsena iznosi približno $86 \%$.

- Predložena metoda predstavlja brz i relativno jeftin način za procjenu sadržaja ekstraktibilnog anorganskog arsena u zemljištu.

- Razlike u procentima ekstraktibilnog arsena u uzorcima $S_{1}$ i $S_{2}$ najvjerovatnije proizlaze iz različitosti hemijskog sastava tla i geoloških supstrata, čije utvrđivanje izlazi iz okvira ovoga rada.

\section{ZAHVALE - Acknowledgements}

Autori se iskreno zahvaljuju Ministarstvu za obrazovanje i nauku Republike Austrije, te Svjetskom univerzitetskom servisu Republike Austrije, WUS-u, na finansijskoj pomoći u realizaciji ovoga rada. Autori se takođe zahvaljuju prof. dr. Vladimiru Beusu na pomoći u realizaciji prikupljanja uzoraka za analizu.

\section{LITERATURA - References}

AdRIANO, D.C. (1986): Trace Elements in the Terrestrial Environment. $1^{\text {st }}$ ed., Springer-Verlag, Berlin.

Aggett, J., AspelL, A.C. (1976): The Determination of Arsenic(III) and Total Arsenic by Atomic Absorption Spectroscopy. Analyst, 101: 341-347.

Anderson, R.K., Thompson, M., Culbard, E. (1986): Selective Reduction of Arsenic Species by Continuous Hydride Generation. Part I. Reaction media. Analyst, 111: 1143-1152. 
Bermejo-Barrera, P., Moreda-Pineiro, J., Moreda Pineiro, A., Bermejo-Barrera, A. (1998): Selective Medium Reactions for the Arsenic(III), Arsenic(V), Dimethylarsonic Acid and Monomethylarsonic Acid Determination in Waters by Hydride Generation on-line Electrothermal Atomic Absorption Spectrometry with in Situ Preconcentration on Zr-c. Analytica Chimica Acta, 374: 231-240.

Charlet, L., Mancean, H. (1993): Structure, formation, and reactivity of hydrous oxide particles; insights from x-ray absorption spectroscopy. In Environmental Particles (eds. Van Leenwen, H.P. and Buffle, J.), Lewis Publishers, Chelsea, MT.

CUlLen, W.R., ReImeR, K.J. (1989): Arsenic Seciation in the Evironment. Chemical Reviews, 89 (4): 713-764.

Driehaus W., Jekel, M. (1992): Determination of As(III) and Total Inorganic Arsenic by on-line Pretreatment in Hydride Generation Atomic Absorption Spectrometry. Fresenius' Journal of Analytical Chemistry, 343: 352-356

Ebdon, L., Hill S.J., Walton, A.P., Ward, R.W. (1988): Coupled ChromatographyAtomic Spectrometry for Arsenic Speciation- A Comparative Study. Analyst, 113: 1159-1163.

GuPtA, S.K., Vollmer, M.K., KREBS, R. (1996): The Importance of Mobile, Mobilizable and Pseudo-total Heavy Metal Fraction in Soil for Three level Risk Assessment and Risk Management. Science of the Total Environment, 178: 1120.

Hall, G.E.M., Gauthier, G., Pelchat, J.C., Pelchat, P., Vaivie, J.e. (1996): Application of a Sequential Extraction Scheme to Ten Geological Certified Reference Materials for the Determination of 20 Elements. Journal of Atomic Spectroscopy, 11: 789-796.

HiRner, A.V. (1992): Trace Element Speciation in Soils and Sediments Using Sequential Chemical Extraction Methods. International Journal of Environmental Analytical Chemistry, 46: 77-85.

Howard, A.G., ARBAB-ZAVAR, M.H. (1981): Determination of Inorganic Arsenic(III) and Arsenic(V), Methylarsenic and Dimethylarsenic Species by Selective Hydride Evolution Atomic-Absorption Spectroscopy. Analyst, 106: 213-220.

HowARD, A.G. (1997): (Boro) Hydride Techiques in Trace Element Speciation. Journal of Analytical Atomic Spectrometry, 12: 267-272

Kersten, M. AND FoRstneR, U. (1995): Speciation of Trace Metals in Sediments and Combustion waste. In Chemical Speciation in the Environment, (eds Ure, A.M. and Davidson, C.M.) Blackie Academic \& Professional, Chapman and Hall, Glasgow, Ireland.

Lopez, A., Torralba, R., Palacios, M.A., Camara, C. (1992): Generation of $\mathrm{AsH}_{3}$ from $\mathrm{As}(\mathrm{V})$ in the Absence of $\mathrm{KI}$ as Prereducing Agent: Speciation of Inorganic Arsenic. Talanta, 39 (10): 1343-1348 
MANNING, B.A., Martens, D.A. (1997): Speciation of Arsenic(III) and Arsenic(V) in Sediment Extracts by High-Performance Liquid Chromatography-Hydride Generation Atomic Absorption Spectrophotometry. Environmental Science \& Technology, 31: 171-177.

Melamed, D. (2004): Monitoring Arsenic in the Environment: A Review of Science and Technologies with the Potential for Field Measurements. U.S. Environmental Protection Agency, (EPA-542-R-04-002), Washington DC.

Michel, P., Averty, B., ColandinI, V. (1992): Improvement in Arsenic Speciation, Using Hydride Generation and Atomic Absorption Spectrophotometry. Mikrochimica Acta, 109: 35-38

MilleR, W.P., MATENES, D.C., ZelAZNY, L.W. (1986): Effect of Sequence in Extraction of Trace Metals from Soils. Soil Science Society of America, 50: 598-601.

Seiler, H.G., Sigel, A., Sigel H. (1994): Handbook on Metals in Clinical and Analytical Chemistry. Marcel Dekker, Inc. New York.

Moderegger, H. (1998): Development of a New Device for the Determination of Arsenic. Master thesis. Karl-Franzens University, Graz, Austria.

NARCISE, C.I.S., Coo, L.D., Del Mundo, F.R. (2005): On-line Preconcentration and Speciation of Arsenic by Flow-Injection Hydride Generation Atomic Absorption Spectrometry. Talanta, 68: 298-304.

NG, J.C., Johnson, D., ImRAY, PChisWell, B., MoORE, M.R. (1998): Speciation of Arsenic Metabolites in the Urine of Occupational Workers and Experimental Rats Using an Optimized Hydride Cold-Trapping Method. Analyst, 123: 929933.

PACEY, G.E., ForD, J.A. (1981): Arsenic Speciation by Ion-Exchange Separation and Graphite-Furnace Atomic-Absorption Spectrophotometry. Talanta, 28: 935-938.

RitCHIE, G.S.P., Sposito, G. (1995): Speciation in Soils. In Chemical Speciation in the Environment, (eds Ure, A.M. and Davidson, C.M.), Blackie Academic \& Professional, Chapman and Hall, Glasgow, Ireland.

Rodriguez, R.R., Basta, N.T., Casteel, S.W., Armstrong, F.P., Ward, D.C. (2003): Chemical Extraction Methods to Assess Bioavailable Arsenic in Soil and Solid Media. Journal of Environmental Quality, 32: 876-884.

Shiowatana, J., Mclaren, R.C., Chanmekha, N., Samphao, A. (2001): Heavy Metals in the Environment. Fractionation of Arsenic in Soil by a Continuous-Flow Sequential Extraction Method. Journal of Environmental Quality, 30: 19401949.

Shraim, A., Chiswell B., Olszowy, H. (2000): Use of Perchloric Acid as a Reaction Medium for Speciation of Arsenic by HG-AAS. Analyst, 125 (5): 949-953.

Sposito, G. (1989): The Chemistry of Soils, Oxford University Press, New York. 
TAHIROVIĆ, A., Čopra-JANIĆIJeVIĆ, A., KALCHER, K., (2010): Razvoj metode za spektrofotometrijsko određivanje arsena. Radovi Šumarskog fakulteta u Sarajevu (u štampi).

TeRLECKA, E. (2005): Arsenic Speciation Analysis in Water Samples: A Review of the Hyphenated Techniques. Environmental Monitoring and Assessment, 107: 259284.

Tessier, A., CAmpbell, P.G.C., Bisson, M. (1979): Sequential extraction procedure for the speciation of particulate trace metals. Analytical Chemistry, 51:848-851.

Thomas, P., FinNie, J.K., Williams, J.G. (1997): Feasibility of Identification and Monitoring of Arsenic Species in Soil and Sediment Samples by Coupled Highperformance Liquid Chromatography - Inductively Coupled Plasma Mass Spectrometry. Journal of Analytical Atomic Spectrometry, 12: 1367-1372.

Torralba, R., Bonilla, M., Palacios, A., Camara, C. (1994): Flow Injection and Continuous Flow System to Determine Arsenic Species As(III) and As(V) by HG-AAS. Analusis, 22: 478-482.

Tsalev, D.N., D'Ulivo, A., Lampugnani, L., Di Marco, M., Zamboni, R. (1995): Thermally Stabilized Iridium on an Integrated, Carbide-Coated Platform as a Permanent Modifier for Hydride Forming Elements in Electrothermal Atomic Absorption Spectrometry. Part 1. Optimization studies, Journal of Analytical Atomic Spectrometry, 10: 1003-1009.

Tuzen, M., Citali, D., Mendil, D., Soylah, M. (2009): Arsenic Speciation in Natural Water Samples by Co-precipitation-Hydride Generation Atomic Absorption Spectrometry. Talanta, 78: 52-56.

Tye, C.T., Haswell, S.J., O' NeIll, P., BanCROFt, K.C.C. (1985): High-Performance Liquid Chromatography with Hydride Generation/Atomic Absorption Spectrometry for the Determination of Arsenic Species with Application to Some Water Samples. Analytica Chimica Acta, 169: 195-200.

WANG, S., Mulligan, C.N. (2008): Speciation and Surface Structure of Inorganic Arsenic in Solid Phase. Environment International, 34: 867-879.

Welz, B. (1998): Speciation analysis. The Future of Atomic Absorption Spectrometry. Journal of Analytical Atomic Spectrometry, 13: 413-417.

Wenzel, W.W., Kirchbaumer, N., Prohaska, T., Stingeder, G., Lombi, E., Adriano, D.C. (2001): Arsenic Fractionation in Soils Using an Improved Sequential Extraction Procedure. Analytica Chimica Acta, 436(2): 309-323.

YeHL, P.M., GuRLEYUK, H., TYSON, J.F., UdEn, P.C. (2001): Arsonic Acid from Soil and Sediment Standard Reference Materials. Analyst, 126: 1511-1518. 
Zeng, J., Goessler, W., Kosmus, W. (1998): The Chromatographic Behavior of Arsenic Compounds on Anion Exchange Columns with Binary Organic Acids as Mobile Phases. Chromatographia, 47: 257-263.

\section{SUMMARY}

This paper presents a simple and inexpensive method for speciation of inorganic arsenic in soil extracts. It is based on selective hydride generation of arsane at different $\mathrm{pH}$ values from the sample solution. A rather acidic $\mathrm{pH}$ value was used for generation of arsane from total inorganic arsenic As(III) and As(V) compounds, and only slightly acidic $\mathrm{pH}$ value was used for the generation of arsane only from $\mathrm{As}(\mathrm{III})$. $\mathrm{As}(\mathrm{V})$ was calculated from difference of total inorganic arsenic and As(III). Determination of total inorganic arsenic was performed with two tablets of amidosulfonic acid (1.7800 $\mathrm{g}$ of acid per tablet) and one tablet of sodium borohydride (3.000 g per tablet). Determination of arsenic(III) was performed in citrate buffer $(0.1$ $\mathrm{mol} / \mathrm{dm}^{3}, \mathrm{pH}=5.5$ ) with one tablet of the reductant. The hydride formed during reaction passed through filter paper, and reacted with mercury bromide giving a colored compound, which was optically detected with a spectrophotometric device SupraLab FD.

Soil samples were collected in two sites of Bosnia. The first site was Vareš region, near the barite, galenite and sphalerite mine (Veovača), and the second one was located at Vranica Mountain, location of Jezernica. Average concentrations of total arsenic determined in digests obtained after mineralization of soils (marked as $\mathrm{S}_{1}$ and $\mathrm{S}_{2}$ ) with nitric acid $(65 \%)$ and hydrogen peroxide $(30 \%)$ were $81.14 \pm 1.90 \mathrm{mg} / \mathrm{kg}$ and $14.18 \pm 0.62 \mathrm{mg} / \mathrm{kg}$, respectively. Obtained recovery rates for spikes in acid digests were in the range $94.0-102 \%$, for the soil $\mathrm{S}_{1}$, and $103.0-104 \%$ for the soil $\mathrm{S}_{2}$.

The procedure by WENZEL (ET AL., 2001) designed for arsenic fractionating in soils was adopted. The sequential procedure employed here consisted of three steps: 0.05 $\mathrm{mol} / \mathrm{dm}^{3}$ ammonium dihydrogen phosphate, which extracts specifically sorbet arsenic from mineral surfaces; $0.2 \mathrm{~mol} / \mathrm{dm}^{3}$ ammonium oxalate $(\mathrm{pH}=3.25)$ which extracts arsenic bound to amorphous and poorly-crystalline hydrous oxides of $\mathrm{Fe}$ and $\mathrm{Al} ; 0.2$ $\mathrm{mol} / \mathrm{dm}^{3}$ ammonium oxalate buffer $+0.1 \mathrm{~mol} / \mathrm{dm}^{3}$ ascorbic acid $(\mathrm{pH}=3.25)$ at elevated temperature $\left(96 \pm 3^{\circ} \mathrm{C}\right)$ which extracts arsenic bound to well crystallized hydrous oxides of $\mathrm{Fe}$ and $\mathrm{Al}$.

The total extractable arsenic in first soil was $77.4 \%$ while in second soil it was $85.9 \%$. The highest amount of arsenic is probably bound to Fe hydroxide (amorphous and crystalline) which presents $76.3 \%$ for soil 1 and $82.6 \%$ for soil 2 of total arsenic content. Generally in two first steps of the extraction procedure only As(V) was detected. Some small amounts of As(III) were detected in the third step of extraction with both soil samples ( $2.8 \%$ for soil 1 and $1.5 \%$ for the soil 2$)$ referred to the total concentration of arsenic in soils in digests with nitric acid. The concentration of 
As(III) measured in citrate buffer was below the detection limit in step 1 and step 2 with both soils.

The reproducibility of the extraction procedure (estimated as RSD of the three repetitive extractions for each step of extraction procedure) was less than $5 \%$, which is in very good agreement with the literature value (WENZEL, ET AL., 2001).

Based on obtained results, the new method using this device is well suitable for trace determination of inorganic arsenic species with concentrations between 0.2 and $20 \mu \mathrm{g} \mathrm{As} / \mathrm{dm}^{3}$. Results obtained shown that the device can be used for such investigations of soils in the laboratory at low costs in routine analysis. 